Slavia Antiqua

LX (2019)

DOI: $10.14746 /$ sa.2019.60.9

GRZEGORZ DOMAŃSKI ${ }^{1}$

\title{
ZE STUDIÓW NAD DZIEJAMI KLASZTORU KANONIKÓW REGULARNYCH NA GÓRZE ŚLĘŻY
}

\author{
STUDIES ON THE HISTORY OF THE REGULAR CANONS \\ MONASTERY ON THE ŚLĘŻA MOUNTAIN
}

\begin{abstract}
Fifteen years after my attempt at summing up the results of the historical, and above all archaeological research on Ślęża mountain (Domański 2002 - research as of 2000) the time has come to make some minor corrections and important additions, mainly related to the early years of St. Augustine's monastery in Ślęża, which from the $12^{\text {th }}$ century to 1494 owned the majority of the massif, and after 1494 the entire mountain.

The location of the monastery on Ślęża has been a matter of discussion since at least the 19th century. Written sources unambiguously speak of its location on the mountain. In 2000, I presented several purported stages of the monastery's construction on top of the mountain. When, following new discoveries, the supposed location of the monastery changed, I put forward the hypothesis that there was a preliminary stage in the monastery's construction (perhaps in cooperation with messengers from the parent monastery) when the materials were collected and the ground was prepared. Next, the monks arrived and almost immediately construction started. Completion (or discontinuation) of construction could have coincided with the monks' flight in 1146 to Wrocław. On the basis of the scant archaeological material discovered in the monastery building, the conclusion should be drawn that no part of it was used. The suggested location of the monastery on the edge of the order's property is an indication that looking after the terrain was not the main goal of the venture. The construction material, traces of the structure's foundations, elements of stonemasonry and the Ślęża plaque all hint at construction having at least commenced, while it remains a mystery at which stage it was abandoned.

Generally, the construction of the Ślęża monastery is associated with the "production" of granite sculptures of lions. More importantly, they were discovered beyond the Ślęża massif, but the majority of researchers attribute them to the monastery. I agree with most art historians that the objects date back to the $12^{\text {th }}$ century. Bearing in mind that in Western and South-European architecture, similar sculptures were placed in pairs at the doors of magnificent buildings, as the bases of columns, the Ślęża lions (8) must have been planned as decoration of four imposing entrances. However, as a majority of them cannot be paired (they were dedicated to two sides of a gate), the number of the original statues must have been greater. The Ślęża lions share many features with similar statues from the St. Gallen abbey; bearing in mind the contacts of the founder (Palatine Peter Wlast), they could have been the prototypes for the Ślęża lions.
\end{abstract}

${ }^{1}$ ORCID: 0000-0002-4231-2198; e-mail grz.domanski@gmail.com. 
Keywords: Poland, Silesia, Ślęża, St. Augustine's monastery, Romanesque period, brick architecture, lion statues, St. Gallen abbey.

Po upływie piętnastu lat od czasu, kiedy starałem się podsumować wyniki badań historycznych, a przede wszystkim archeologicznych, na górze Ślęży (Domański 2002 - stan badań z 2000 r.), w tym także dziejów ślężańskiego klasztoru Kanoników Regularnych św. Augustyna, który od XII w. do roku 1810 był właścicielem masywu, początkowo jego większej części, a z czasem całości (por. Korta 1988, 234-282), konieczne jest wprowadzenie (niewielkich) korekt i istotnych uzupełnień, głównie dotyczących pierwszych lat działania klasztoru na Ślęży. Zmiany są konieczne ze względu na potrzebę uzupełnienia i przewartościowanie problematyki po uwzględnieniu wyników badań przeprowadzonych już po napisaniu książki, a te były bardzo intensywne. Najważniejsze to badania zamku na szczycie (Kastek, Krzywka, Limisiewicz i Mruczek 2016, s. 281-312; Kastek, Limisiewicz i Mruczek 2013, s. 302-320), badania prepozytury w Górce (Stala 2010, s. 67-78; 2010a, s. 91-100; 2011, s. 471-486; 2013, s. 289-302) i jej okolic oraz kontynuacja badań w okolicy „panny z rybą” wewnątrz wału półksiężycowatego (Domański, 2005, s. $55-66 ; 2006$.)

Uposażenie klasztoru ślężańskiego na Ślęży i w okolicy od czasu fundacji niewiele się zmieniło do późnego średniowiecza, a nawet czasów nowożytnych (Korta 1988, s. 316-326, Pobóg-Lenartowicz 1992, s. 89-90; 1994, s. 10-19). Obszar masywu z wyłączeniem Będkowic i Sulistrowic (zakupionych przez klasztor w 1494 r.), związanych najściślej z rodem fundatora (por. Domański 2002, 107-111), do roku 1810 należał niezmiennie do klasztoru. Informacje o przejmowaniu całego masywu przez klasztor i odbieraniu części przez księcia polegają na nadinterpretacji dokumentów, które w rzeczywistości nie mówią o posiadaniu przez klasztor c ałej góry.

Brak także dokumentów potwierdzających przynależność szczytu góry do klasztoru. Wszystkie informacje dotyczące partii szczytowej góry dotyczą grodu kasztelańskiego (książęcego) i zamku (książęcego). Możliwe jest wyłączenie szczytu z posiadłości Piotra Włosta i jego rodziny na korzyść panujących Piastów, także wcześniej w czasie inkorporacji Śląska do państwa piastowskiego. (Podobnie kluczowe punkty - grody zatrzymał sobie Władysław Herman, wydzielając dzielnice synom, i Bolesław Kędzierzawy, oddając Śląsk synom Władysława Wygnańca (Zientara 2008, s. 58). Można przypuszczać, że większość granic klasztoru wyznaczonych przez Piotra Włosta przetrwała do schyłku wczesnego średniowiecza. Na własność klasztoru fragment góry przeszedł wraz zakupem pozostałej części masywu i wtedy (1554) także możliwe było wybudowanie kościoła klasztornego na szczycie (Korta 1988, s. 286). Mimo, że klasztor już w średniowieczu posiadał liczne dobra rozrzucone w całej Polsce (Pobóg-Lenartowicz 1994, s. 35) - dobra ślężańskie stanowiły istotną ich część, obejmując duży areał pól uprawnych (również na zboczach góry, czego do niedawna nie brano pod uwagę; por. Domański 
2002, s. 47, 115; 2006) - a także znaczny obszar lasów, tym cenniejszych, że pobliskie tereny były już $\mathrm{w}$ znacznym stopniu odlesione, a lasy $\mathrm{z}$ terenu masywu stanowiły duży rezerwuar materiału budowlanego i opału, a także miejsce wypasu bydła i trzody.

W początkowym okresie wszystkie lub prawie wszystkie posiadłości klasztoru na Ślęży były efektem fundacji możnowładcy pochodzącego ze Śląska Piotra Włosta (por. Bieniek 1965, s. 15-58; Korta 1964, s. 21-25, 68-69; 1988, s. 318-326; Pobóg-Lenartowicz 2007, s. 22). Fundację poza tradycją zakonną potwierdzają dokumenty pisane zarówno z okresu jej powstawania, jak i z czasu funkcjonowania klasztoru na Ślęży, m.in. bulla papieża Eugeniusza III (Maleczyński, KdS I, nr 22) i dokument biskupa wrocławskiego Waltera (Maleczyński, KdS, I, nr 26). Podstawą darowizny były wsie wymieniane we wczesnych źródłach: Wiry, Mysłaków, Zebrzydów, Biała, Strzelce, Chwałków, Sobótka i Strzegomiany (por. Korta 1988). Brak dokładnych informacji o pochodzeniu i czasie przyłączenia do klucza ślężańskiego części posiadłości klasztornych wzmiankowanych w latach 1150-1250, wieś Wino przed 1193, folwark w Górce powstał przed rokiem 1204, wieś Tąpadła przed 1209, Gogołów przypuszczalnie przed 1193, a Garncarsko przed 1250. Poza darowiznami trzeba brać pod uwagę także akcję kolonizacyjną klasztoru (Pobóg -Lenartowicz 1994, s. 106-110; 2007, s. 25). Do połowy XIII w. obszar posiadłości powiększył się prawie dwukrotnie. Na jego najbardziej od Ślęży oddalonym północnym narożniku postawiono słup graniczny, dzisiaj zwany „Mnichem”.

W stosunku do pierwotnego uposażenia powszechnie przyjmowana jest fundacja Piotra Włosta możnowładcy, palatyna Bolesława Krzywoustego, a później najstarszego jego syna księcia-seniora Władysława (Wygnańca). Najwyższego urzędnika w państwie spełniającego doraźnie w zastępstwie władcy (ów) funkcje dowódcy wojsk, wykonawcy różnego rodzaju misji zagranicznych i zastępującego władcę w licznych obowiązkach wewnątrz państwa. Posiadanie licznych dóbr na Dolnym Śląsku, a szczególnie kompleksu obejmującego Ślężę pozwala wiązać jego rodowód z tym regionem, a zwłaszcza ze Ślężą, którą bez wątpienia miał w całości. Można sugerować, że pochodził on z rodu dawnych władców lokalnych (Małachowicz 2000, s. 30, 32, 36,46-47). Biorąc pod uwagę informację z bulli papieża Eugeniusza III (Maleczyński, KdS I, nr 22) z 1148 r. o tym, że tereny będące przedmiotem donacji należały do ojca i dziadka Piotra Włosta, można przypuszczać, że należały do jego rodu i wcześniej, a zwarty ich obszar może sugerować, że były to posiadłości dawnych książąt plemiennych podporządkowanych przez Piastów w momencie włączenia Śląska do ich państwa (por. Uhtenwoldt 1940, s. 10-16; Maleczyński 1960, s. 186, 187; Bieniek 1965, s. 31-38; Małachowicz 2000, s. 49-51). W tej sytuacji można domniemywać, że jego przodkowie byli opiekunami pogańskiego ośrodka kultowego na Ślęży, wspominanego przez Thietmara (Jedlicki 1950, s. 554-555). Trzeba tu dodać, że w XI w. przodkowie Piotra Włosta byli przypuszczalnie właścicielami grodu w Będkowicach, jedynej warowni w całym masywie. 
Fundacja klasztoru w tym miejscu mogła być posunięciem ekspiacyjnym za „winy” przodków (por. Domański 2000, 105)

Zagadkowy jest wybór kanoników regularnych z Arrovese do osadzenia w tym miejscu (Pobóg-Lenartowicz 1992). Można przypuszczać, że w trakcie podróży do zachodniej Europy lub dzięki kontaktom z wybitnymi postaciami kultury (np. korespondencja ze św. Bernardem por. Maleczyński, CdS I, kontakty z opactwem Saint-Gilles (Derwich 1998, s. 86-87) z tego obszaru Piotr Włost nawiązał kontakty ze wspólnotą arrowezyjską (por. Deptuła 1967, s. 29-31) . Na podstawie analizy dokumentów głównie klasztoru w Arrovaise można przyjąć, że mnisi z tego klasztoru dotarli na Ślężę około roku 1138-1140 (por. Korta 1988, s. 276-277, Milis 1971, s. 10-14, 24-26, Żerelik 1999, s. 27-28; Kogut 2005, s. 92) i rozpoczęli budowę klasztoru, co było celem ich misji. Można domniemywać, że wstępne przygotowania mógł poczynić fundator od momentu zaproszenia do czasu przybycia pierwszych zakonników (por. Świechowski 2011, s. 10). Nie wiemy także, jak wielkie siły postawił fundator do dyspozycji klasztoru, a tym samym jak szybko postępowały prace. W większości na domniemaniach opierają się daty rozpoczęcia i zakończenia, a raczej przerwania samego procesu budowy klasztoru. Tragedia, jaka spotkała fundatora klasztoru (oślepienie, wyrwanie języka, konfiskata dóbr, banicja) na początku 1146 r. (Bieniek 1965, s. 64-72), niewątpliwie spowodowała przerwanie prac nad wznoszeniem klasztoru, dyskusyjna, ale bardzo prawdopodobna jest teza, że przerwane wówczas prace nigdy już nie zostały wznowione. Byłoby to szczególnie uzasadnione, gdyby udział ludzi fundatora w trakcie prac budowlanych był znaczny.

Przeniesienie klasztoru w tym czasie do Wrocławia było po prostu ucieczką mającą na celu ochronę zdrowia i życia zakonników, którzy w obcym środowisku zostali pozbawieni opieki fundatora (por. Milis 1971, s. 20; Domański 2002, s. 111; Pobóg-Lenartowicz 2007, s. 23; Mandziuk 2007, s. 56-57). Pretekst o ucieczce przed złym klimatem zastąpił prawdziwy powód, którym było działanie ojca aktualnie panującego, mieszkającego kilkaset metrów od klasztoru. Można jednak brać pod uwagę dwustopniową translację. Ucieczkę zakonników w roku 1146 do Wrocławia (pod opiekę brata Piotra Włosta, Bogusława) i utrzymanie formalne klasztoru ślężańskiego do lat pięćdziesiątych, kiedy nastąpiła decyzja o przeniesieniu go jako instytucji do Wrocławia (m.in. Maleczyński 1950, s. 16, Korta 1988, s. 328). Być może fakt ten nastąpił w momencie, kiedy możliwe było przeniesienie do własnych zabudowań na wyspie Piasek, co mogło nastąpić niedługo po śmierci dobroczyńcy (1153). O pośpiechu przy budowie mogły świadczyć niewielkie rozmiary wzniesionego tam kościoła (por. Świechowski 2011, s. 16). Przy rozpatrywaniu czasu budowy nie lekceważyłbym (por. Korta 1988, s. 329) możliwości przeniesienia budowniczych (szczególnie wykonujących podstawowe prace budowlane) ze Ślęży do Wrocławia, co przyczyniło się szybkiego postępu prac budowlanych. Nie można, sądząc po wynikach, zakładać, że w obu wypadkach działał ten sam zespół, jednak doświadczenia zdobyte na Ślęży mogły się przydać 
we Wrocławiu tym bardziej, że do budowy używano tego samego materiału (granitu ślężańskiego). Warto zwrócić uwage na fakt, że oba podstawowe dokumenty bulla papieża Eugeniusza III z roku 1148 i dokument biskupa Waltera z 1149/1450 - mają na celu zabezpieczenie dóbr klasztornych, ich integralności, a może nawet istnienia klasztoru, po klęsce fundatora i opiekuna na przełomie 1145/1146 roku. Następny dokument dotyczący Ślęży - bulla papieża Celestyna III z roku 1193 (CdS I, 71) - została napisana ponad 40 lat później i miała podobny cel. Podsumowuje ona wydarzenia $z$ lat $1150-1193$, m.in. sytuację klasztoru po śmierci fundatora (1153) i wyemigrowaniu ze Śląska do innych dzielnic Polski członków jego rodziny (por. Maleczyński 1960, s. 328). Podsumowaniem tych zabiegów był obchód posiadłości ślężańskich klasztoru (wtedy już wrocławskiego) przez Henryka Brodatego w 1209 roku (Maleczyński, Skowrońska, CdS II, 135).

Przynajmniej od XIX w. jest dyskutowana sprawa lokalizacji klasztoru ślężańskiego. Źródła pisane mówią jednoznacznie o położeniu in montem (Korta 1981, s. 27-33; 1988). Może to jednak oznaczać wszystkie partie góry od szczytu do podnóża. Jak wspomniałem powyżej, szczyt prawie cały czas należał do władz państwowych tak jak i znajdujące się tam urządzenia obronne. Przypuszczalnie od początku klasztor (kilku zakonników) nie był w stanie utrzymywać samodzielnie załogi dla obrony tych urządzeń. Sama lokalizacja poza aspektem ideologicznym (zastąpienie ośrodka pogańskiego chrześcijańskim por. Żerelik 1999, s. 29) byłaby zaprzeczeniem posłannictwa klasztoru, który miał na celu opiekę duszpasterską i szerzenie wiary (Matusik 1974, s. 45; Kogut 2005, s. 95; Mandziuk 2007, s. 55), a budowa na szczycie wysokiej i trudno dostępnej góry byłaby raczej narzędziem separacji od wiernych. Dodatkowym argumentem przeciw istnieniu na szczycie kościoła i przynależnej parafii jest brak miejsca na parafialny - klasztorny cmentarz (Maleczyński 1950, s. 11)

Dotychczasowe badania archeologiczne (por. m.in. Domański 2002, s. 10-23, tam wcześniejsza literatura; Kastek, Limisiewicz i Mruczek 2013, s. 302-320; Kastek, Krzywka, Limisiewicz i Mruczek 2016, s. 281-312) na szczycie nie potwierdziły istnienia tam wczesnośredniowiecznego kościoła ani zabudowań klasztornych, chociaż istnienie kościoła w grodzie kasztelańskim i w późniejszym zamku jest wysoce prawdopodobne, co podkreślają autorzy badań (Kastek, Limisiewicz i Mruczek 2013, s. 316).

Drugą bardzo popularną w literaturze lokalizacją jest Górka, w której w 1204 r. poświadczona jest ekspozytura klasztoru NMP na Piasku, dla zarządzania dobrami ślężańskimi (Maleczyński, KdS, I, nr 105). Górka niewystępująca do 1204 w źródłach pisanych, staje się ,stolicą” i centrum zarządzania augustiańskich dóbr klasztornych na Ślęży (por. Korta 1981, s. 28-33; 1988, s. 293-301). Brak śladów osadnictwa do schyłku XIII w. (Geschwendt 1942, s. 58-62; Korta 1988, s. 294; Żerelik 1999, s. 33; Domański 2002, s. 74) na miejscu budowy kościoła i dalszych zabudowań związanych z późniejszą prepozyturą klasztoru Kanoników Regularnych nie świadczy o budowie na terenie pustym osadniczo, jak przyległe tereny 
masywu. W najbliższym sąsiedztwie kościoła związanego z grangią odkryto osadę z wczesnych faz wczesnego średniowiecza (VIII-IX w.), a u podnóża wzgórza, na którym znajduje się kościół, osadę ze średniowiecza (Domański 2006, s. 5-6). Przed badaniami z XXI w. powszechnie sądzono, że brak śladów osadnictwa wczesnośredniowiecznego na wzgórzu, gdzie posadowiono kościół i zabudowania związane z prepozyturą, może być efektem licznych późniejszych prac budowlanych, które doprowadziły do niwelacji nawarstwień związanych z osadą z późnych faz wczesnego średniowiecza (por. m.in. Cehak-Hołubowiczowa 1958, s. 18) bezpośrednio poprzedzającą budowę zabudowań prepozytury. Jednak szeroki zakres ostatnich badań (por. Stala 2010; 2010a; 2011; 2013) pozwala na jednoznaczne wykluczenie istnienia śladów użytkowania tego obszaru we wczesnym średniowieczu.

Odkryte w trakcie ostatnich badań romański kościół i fragment przyległych zabudowań interpretuje się jako palatium Piotra Włosta (Stala, 2010; 2011; 2013). Na podstawie analizy sposobu wykonania ścian przesuwa autorka datowanie tego obiektu z powszechnie przyjmowanej połowy XIII w. na połowę XII wieku. Zabieg ten jest próbą dopasowania datowania (por. uwagi Z. Świechowskiego 2011, s. 14-15) do swoiście interpretowanych faktów znanych ze źródeł pisanych. Jednak, jeżeli Piotr Włost, nie wspominając o tym drobiazgu, przekazał swoje palatium zakonnikom, którzy je wykorzystywali w 1 połowie XII w., jeżeli ustąpił je w latach trzydziestych XII w., musiał je wybudować na początku XII w. lub może jeszcze w XI wieku. Jeżeli natomiast podjął budowę około połowy XII w., to budował palatium z przeznaczeniem na klasztor w samym środku posiadłości klasztornych, które wcześniej podarował klasztorowi Kanoników Regularnych.

Przynajmniej dyskusyjne jest, przy stałym zaangażowaniu właściciela w budowę kościołów w całej Polsce, istnienie palatium Piotra Włosta bez kościoła lub przynajmniej kaplicy jako pierwszego i najważniejszego elementu budowli.

Mało prawdopodobne jest także istnienie palatium możnowładczego, na dodatek o położeniu domku letniskowego, gdy stała jego siedziba wraz z całym zapleczem gospodarczym znajdowała się we Wrocławiu na Ołbinie (por. Uhtenwoldt 1936; 1940, s. 2, 11-12; Małachowicz 2000, s. 49-51).

W dokumencie z 1204 r. po raz pierwszy pojawiła się wiadomość o folwarku w Górce (ze spichlerzem w roku 1250 - Maleczyński 1950, s. 14) który wzmiankowany kilkakrotnie w źródłach klasztornych z 1 połowy XIII w., i grangia, składnica dziesięcin i innych materialnych składników powinności na rzecz klasztoru ze ślężańskich jego posiadłości (Korta 1988, s. 298). Wyniki badań archeologicznych wykluczają istnienie śladów osadnictwa w miejscu, gdzie później wybudowano kościół, natomiast można przypuszczać, że folwark powstał kilkadziesiąt lat przed pojawieniem się w źródłach, spełniając rolę, którą od 1204 r. spełniał oficjalnie. W roku 1204 folwark w Górce posiadał dwa woły i konia (Maleczyński, CdS I, 105). Kościół w Górce powstał na krótko przed 1250 r., kiedy był po raz pierwszy wzmiankowany w źródłach, wtedy możemy mówić o istnieniu prepozytury. Ana- 


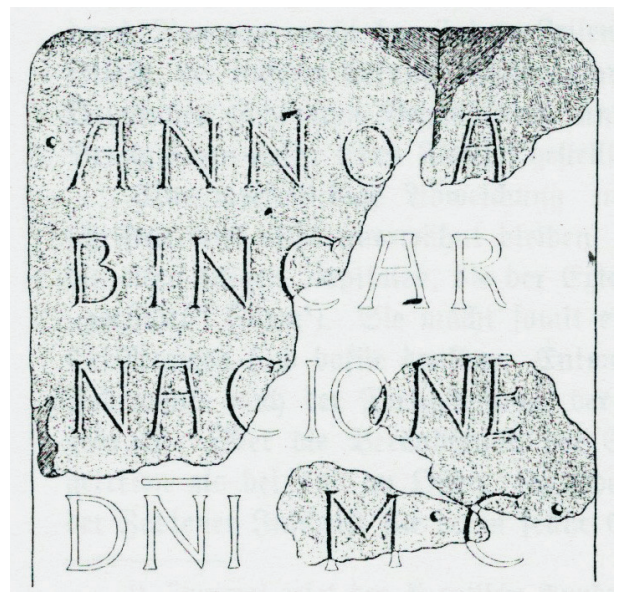

Ryc. 1. Tzw. Tablica ślężańska

liza źródeł pisanych, archeologicznych i architektonicznych daje taki sam wynik co do daty powstania budowli romańskiej Górce (Korta 1988, s. 293-299; Domański 2006 i por. wyżej; Świechowski 2009, s. 434-437).

Górka jako jako miejsce posadowienia klasztoru występuje także często ze względów etymologicznych, gdy stawia się znak równości góra - Górka, jednak w każdym wypadku sugestie te nie mają podbudowy w źródłach (por. Korta 1988, s. 287).

Trzecim miejscem noszącym ślady przygotowań do budowy obiektu o dużej skali $\mathrm{w}$ obrębie masywu jest miejsce otoczone z jednej strony wałem (Cehak-Hołubowiczowa 1958, s. 17; Słupecki 1992, s. 8-9; Domański 2002, s. 24-30), przypuszczalnie będącym podstawą palisady o nieokreślonym datowaniu (por. Domański 2002, s. 89), gdzie odkryto szereg elementów budowlanych związanych z budową budynku lub budynków z czasu powstania klasztoru, a przede wszystkim tzw. tablicę ślężańską (ryc. 1), swoisty akt erekcyjny klasztoru (por. Świechowski 2011, s. 12). Tablica nosi ślady rozbicia za pomocą twardego narzędzia, może siekiery (Lustig 1926, s. 57; 1928a, s. 4). Czynu tego dokonano na miejscu znalezienia. Trudno sobie wyobrazić transport ciężkiego bloku skalnego z innego miejsca w masywie na miejsce zniszczenia. W trakcie badań wykopaliskowych w latach 1908-1910 w pobliżu miejsca znalezienia tablicy odkryto fragment rzeźby kamiennej, tzw. głowę sfinksa, fragment kamiennego obramowania romańskiego okienka i nadproża oraz liczne obrobione fragmenty bloków i płyt granitowych. To nagromadzenie elementów architektonicznych skłoniło do lokalizowania tam pracowni kamieniarskiej pracującej dla potrzeb budowy klasztoru (Korta 1988, s. 192). Wymienione odkrycia skłoniły liczną grupę badaczy do lokalizacji w tym miejscu klasztoru lub związanej z nim kaplicy (Lustig 1925, s. 87, 88; 1926, s. 19; 1928, 


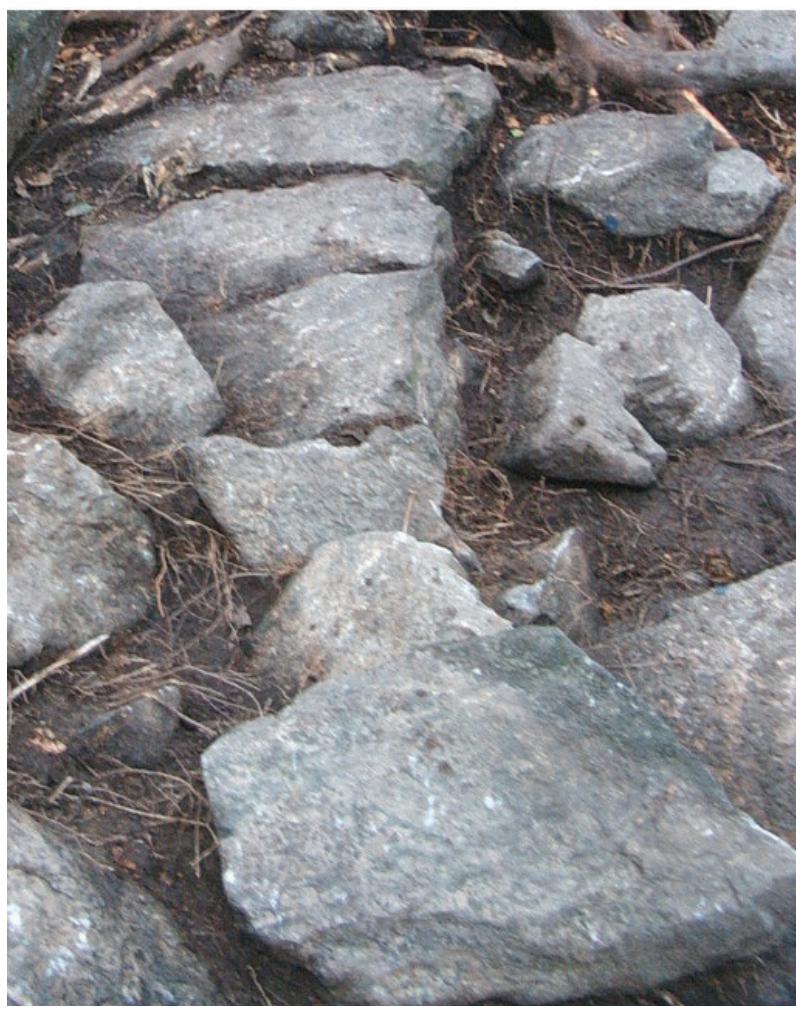

Ryc. 2. Ślęża 10, podwaliny budynku

s. 28-29; Geschwendt 1938, s. 35; Uhtenwoldt 1937, s. 14-15; 1938, s. 72-85; Maleczyński 1950, s. 16-19; Semkowicz 1949, s. 29; Domański 2002, s. 29)

W latach 2004-2005 wznowiono badania na tym stanowisku. Przebadano przestrzeń 2 arów przylegającą od południowego wschodu wspomnianego wykopu G. Lustiga z początku XX wieku. Obszar terenu badań była ograniczony dwoma zagłębionymi drogami biegnącymi ze szczytu do Sobótki zaburzającymi pierwotny układ warstw. W wykopie odkryto liczne bloki granitu ze śladami obróbki (ryc. 3) i półkolisty układ z kamieni o górnych płaszczyznach na jednakowym poziomie (ryc. 2), przypuszczalnie stanowiący podwalinę konstrukcji drewnianej (lub kamiennej?). Wspomniany układ odkryty na długości $3 \mathrm{~m}$ ma kształt fragmentu koła o średnicy około $10 \mathrm{~m}$

W obrębie wykopu w niewielkiej ilości humusu odkryto ceramikę kultury łużyckiej, z wczesnego i późnego średniowiecza, oraz materiały nowożytne. W kilku punktach wykopu odkryto 17 ułamków naczynia górą obtaczanego z późnych faz wczesnego średniowiecza, które w całości zrekonstruowano rysunkowo (ryc. 4). Odkryte naczynie sposobem wykonania nawiązuje do ceramiki wczesnośrednio- 


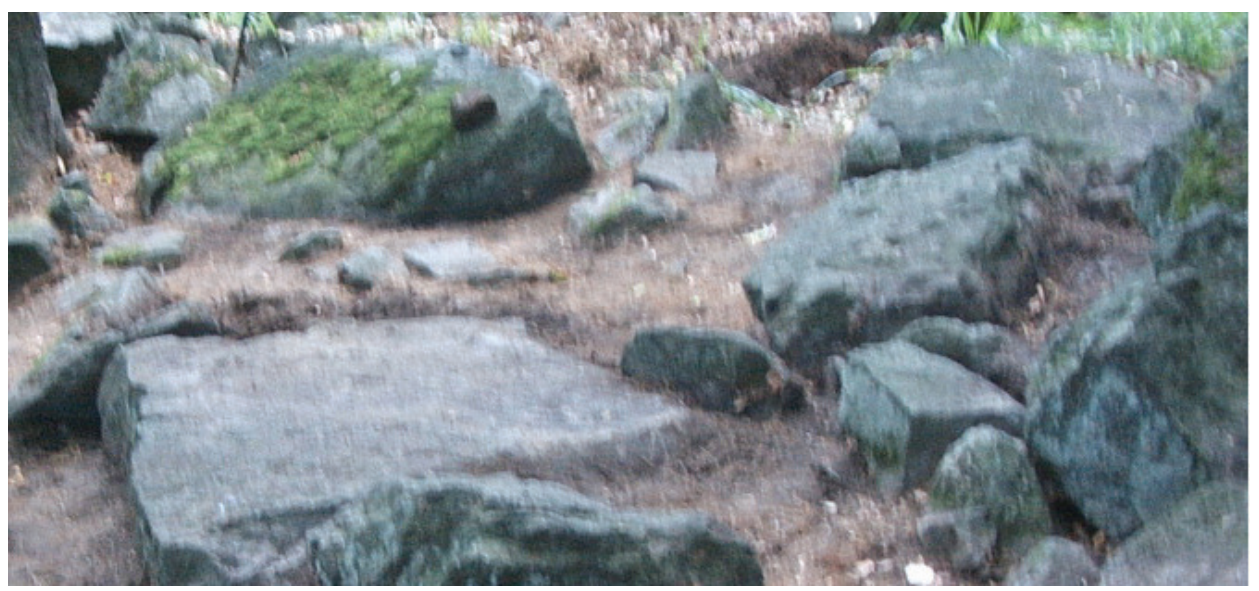

Ryc. 3. Ślęża 10, bloki granitu ze śladami obróbki

wiecznej, jednak sposób jego zdobienia niespotykany na Śląsku jest powszechnie stosowany we Flandrii, ojczyźnie zakonników - kanoników regularnych św. Augustyna (por. m.in. Braat 1937, s. 167, ryc. 7:4; 8:34; 12:4; tabl. 42:2; Van Es 1969, s. 200, typ IIIA; 201, ryc. 19:1).Wspomniane odkrycia wzmacniają tezę o budowie klasztoru ślężańskiego właśnie w tym miejscu. Rzeźby z okresów wcześniejszych - „panna z rybą”, niedźwiedź zostały zabezpieczone przed ponownym użyciem przy budynku klasztornym.

Dodatkowo wzmacniają tę tezę odkrycia hałd materiałów budowlanych zgromadzone na krawędzi najwyżej położonego pola kamieniołomów (stan. 25) z okresu wpływów rzymskich i początków okresu wędrówek ludów (Domański 2002, s. 34, 39). W średniowieczu poza tradycyjną (kontynuowaną lub wznowioną od okresu wpływów rzymskich) produkcją żaren stała się Ślęża miejscem pozyskiwania kamienia budowlanego w bardzo dogodnej formie naturalnie ukształtowanych graniastych kostek i płyt łatwych do zastosowania przy budowie monumentalnych budowli, głównie kościołów. Trzeba tu podkreślić, że graniaste fragmenty granitu wydobyte ze złoża, wcześniej były całkowicie nieprzydatne do produkcji żaren, gdzie wymagane były płyty o odpowiednio dużej powierzchni i o nieznacznej grubości, teraz pożądane były kawałki granitu o kształcie przydatnym do celów budowlanych, a więc w kształcie kostek pasujących do innych tego rodzaju elementów budowlanych. Zgromadzenie hałd tych materiałów z powierzchni pól kamieniołomów lub płytkich odkrywek było bez porównania łatwiejsze niż wydobywanie ich spod, czasem kilkumetrowej, warstwy zwietrzeliny. Przy odpowiednim nakładzie pracy zgromadzenie hałd o wielkości takiej jak na stanowisku 25 mogło trwać kilka miesięcy. Wydobycie kamienia z innych miejsc na zboczach Ślęży w miejscach, gdzie wcześniej nie prowadzono eksploatacji granitu, zwięk- 


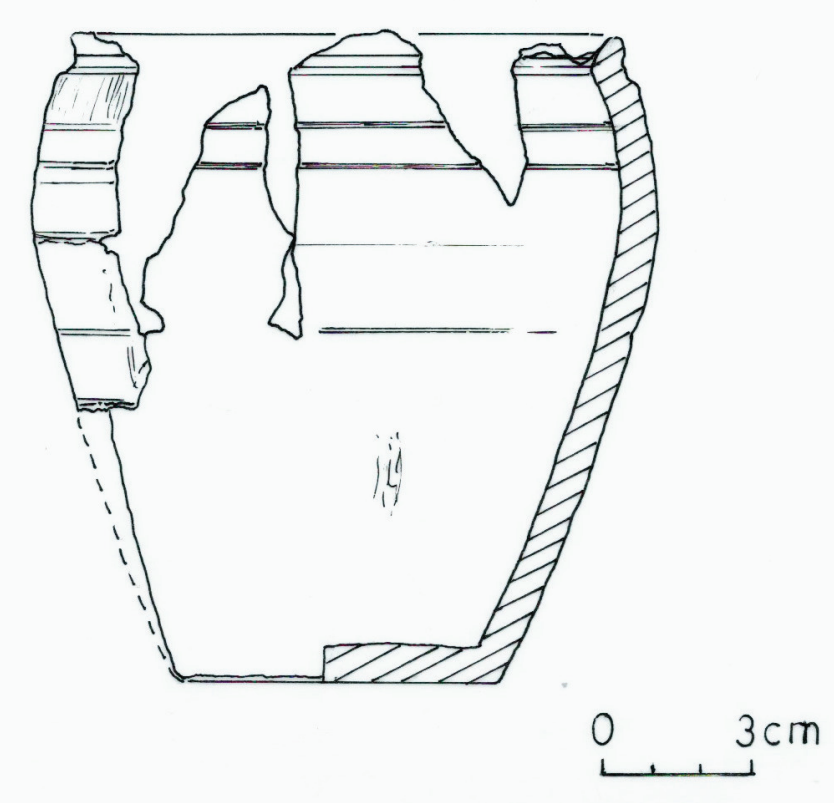

Ryc. 4. Ślęża 10, naczynie odkryte w gruzie skalnym

szało pracochłonność kilka-, a nawet kilkunastokrotnie. Zgromadzenie kamienia budowlanego, w miejscu gdzie go odkryto, wskazuje na plac budowy w obrębie masywu, przypuszczalnie na podobnej wysokości lub wyżej, a pozostawienie go do dna dzisiejszego wskazuje na gwałtowne przerwanie budowy. Odkrycie w pobliżu wspomnianych hałd uszkodzonych elementów budowlanych (być może ślad pracowni) wskazuje na produkcję w ich pobliżu gotowych elementów architektonicznych, często o gładkich, wypolerowanych powierzchniach (Domański 2002, s. 37, 39) przeznaczonych do montowania w murach wznoszonej budowli. Przy wspomnianej lokalizacji domniemanego placu budowy transport wyselekcjonowanego materiału wymagał pokonania wysokości około $100 \mathrm{~m}$ drogą wznoszącą się łagodnie do góry (kamień budowlany na wysokości 380-405 m n.p.m., domniemane miejsce budowy 495-505 m n.p.m.), z kamieniołomów w okolicy (jeżeli wówczas funkcjonowały) Sobótki-Górki około $270 \mathrm{~m}$ w pionie drogą (Lustig 1934, 345 , ryc. 1) biegnącą ostro do góry. Do końca nie wyjaśniono, czy podobne hałdy znajdowały się przy innych krawędziach pola lejów na omawianym stanowisku 25 i przy innych polach. Na podstawie dotychczasowych ustaleń wspomnianej selekcji dokonano i zlokalizowano warsztat produkujący elementy architektoniczne tylko przy najwyżej położonym polu kamieniołomów na stanowisku nr 25 . Wspomniane pole znajduje się $\mathrm{w}$ odległości $2300 \mathrm{~m}$ od domniemanego miejsca budowy, trzeba tu jeszcze dodać, że w pobliżu górnej krawędzi granitowej części 


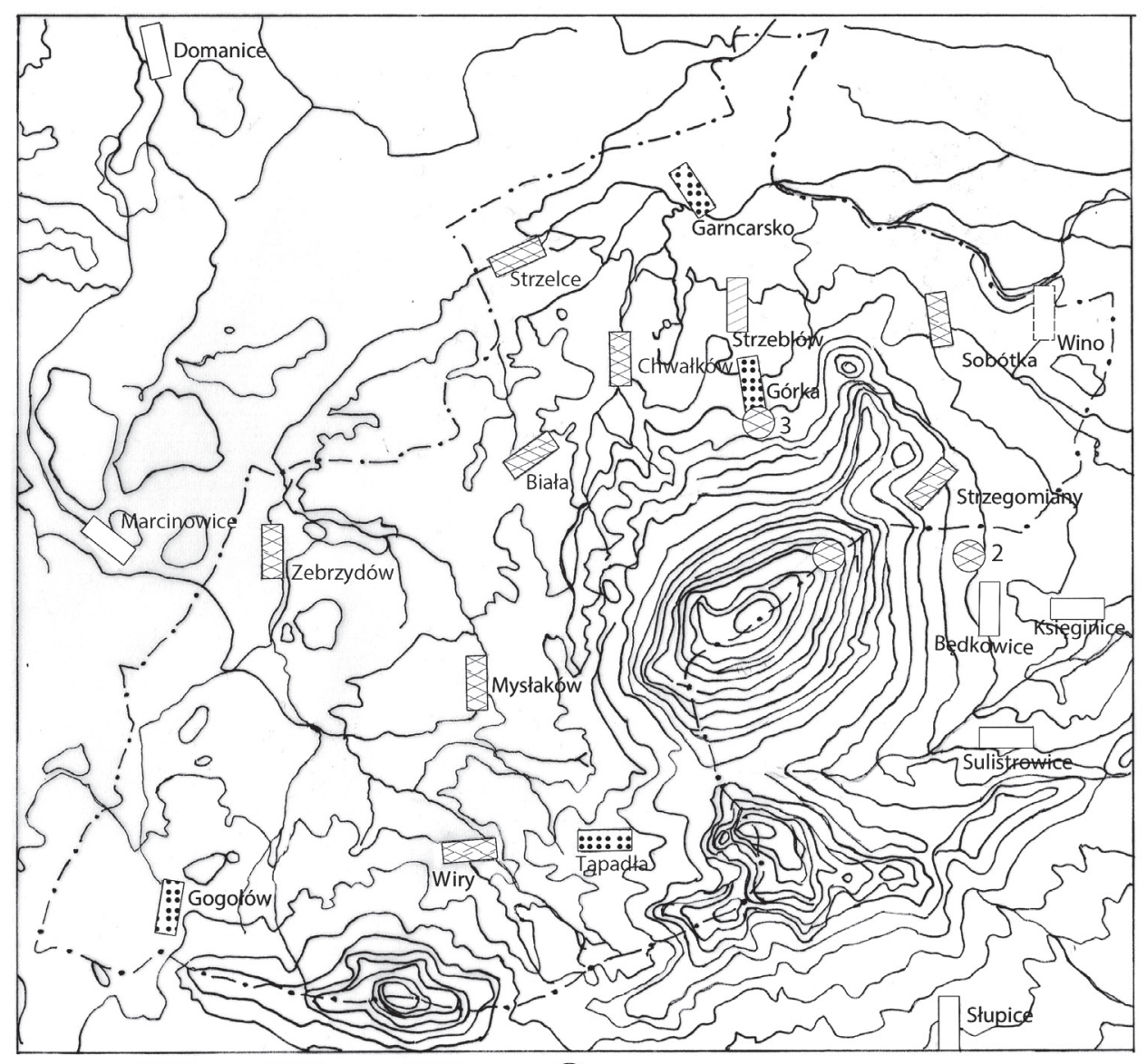

ख-1 ए-2 :::::!-3 $3-4$ \&-5 -.-- 6

Ryc. 5. Ślężańskie posiadłości klasztoru NMP: 1. Wsie z pierwotnej fundacji Piotra Włosta; 2. Fundacja biskupa Waltera?; 3. Wsie będące wynikiem kolonizacji i nabyte do połowy XIII w.

5. 1 - klasztor, 2 - gród w Będkowicach, 3 - grangia w Górce, 6 - granice posiadłości klasztornych w połowie XIII wieku

Ślęży. Wyższa część masywu zbudowana jest z gabra skały o znacznie gorszych parametrach, jako materiału budowlanego, natomiast granit ślężański do dziś jest eksploatowany i używany, jako doskonały materiał budowlany. Wspomniane kamieniołomy są najwyżej położonym udokumentowanym źródłem granitowego surowca budowlanego na Ślęży.

$\mathrm{Z}$ budową na proponowanym miejscu mogła być także związana osada, gdzie najprawdopodobniej dokonywano obróbki elementów kamiennych w odległości około $70 \mathrm{~m}$ od placu budowy, na podstawie odkrytego materiału datowana od połowy XII-XIII wieku. (Kaźmierczyk 1994, s. 358). 
Argumentem za wspomnianą lokalizacją klasztoru mogła być także bliskość źródła (św. Jakuba) wody pitnej położonego w odległości $200 \mathrm{~m}$ i $40 \mathrm{~m}$ poniżej domniemanego miejsca budowy klasztoru (por. Błażejewski 1994).

Patrząc od strony stosunków własnościowych, klasztor znajdował się na granicy posiadłości klasztornych i fundatora, w pobliżu rodowej (co nie znaczy aktualnej) jego siedziby (1900 m od grodu w Będkowicach). Wychodząc od funkcji klasztoru, poza działalnością na dużym terenie wokół masywu, mógł spełniać także funkcje liturgiczne $\mathrm{w}$ stosunku do fundatora jego rodziny i dworu. Z drugiej strony bliskość grodu i załogi wojskowej lub przynajmniej zamieszkanego przez załogę wojskową gwarantowała klasztorowi bezpieczeństwo, a także schronienie bez konieczności budowy prowizorycznych zabudowań w pobliżu placu budowy.

Dodatkową przesłanką dla lokalizacji klasztoru mogła być bliskość $(750 \mathrm{~m})$ mikroskopijnego już w tym czasie niefunkcjonującego gródka na wschodnich zboczach Ślęży i sztucznego zbiornika wody (stawem) najprawdopodobniej związanego z kultem pogańskim (Domański 1995; 1996; 1997; 2002, 55-62). Bliskość klasztoru mogła przeciwdziałać próbom potajemnego wykorzystywania tego miejsca (ruiny grodu, staw) dla sprawowania pogańskich obrzędów.

Sytuacja klasztoru zmieniła się diametralnie w chwili upadku Piotra Włosta. Najważniejsza była utrata poczucia bezpieczeństwa, ucieczka do Wrocławia, a w dalszej perspektywie decyzja o pozostaniu w nowym miejscu. Wspomniana lokalizacja utraciła większość swoich atutów, plac budowy znalazł się na granicy posiadłości książęcych (przejściowo w roku 1146, przypuszczalnie na stałe około 1173) skończyła się bezpośrednia opieka fundatora. (por. Deptuła 1967, s. 30; Pobóg-Lenartowicz 2007, s. 22, 23). Konsekwencją wspomnianych faktów była rezygnacja z kontynuacji budowy klasztoru na Ślęży i rozpoczęcie nowego życia we Wrocławiu.

Przerwanie budowy klasztoru na Ślęży miało swoje konsekwencje dla struktury zakonu. Przeniesienie centrum dyspozycyjnego gospodarki zakonu do Wrocławia spowodowało potrzebę, a może konieczność budowy centrum administracyjnego ślężańskich jego dóbr. Centrum takie musiało posiadać budynek mieszkalny - dwór i magazyn, w dalszej kolejności gospodarstwo rolne. Początkowo mogła to być grangia $\mathrm{w}$ rozumieniu południowoeuropejskim spełniająca funkcję magazynu wszelkich powinności materialnych poddanych klasztornych z dóbr ślężańskich. Prepozytura w pełnym tego słowa znaczeniu powstała około połowy XIII w. w momencie budowy kościoła, kiedy do funkcji gospodarczych sprawowanych przez świeckich lub zakonników o niepełnych prawach doszły funkcje sakralne, a placówka stała się częścią macierzystego klasztoru i siedzibą części konwentu.

$\mathrm{Z}$ dużym prawdopodobieństwem budowę ułatwiało wykorzystanie materiałów budowlanych zgromadzonych lub częściowo użytych przy budowie klasztoru w omawianym miejscu. W tym wypadku trzeba się liczyć z użyciem elementów budowlanych wymagających dużego nakładu pracy, jak np. portal znajdujący się obecnie w Górce odpowiadający chronologicznie okresowi budowy klasztoru (por. Hawrot 1949; Kozaczewski 1957; Korta 1981, s. 30). 
Centralny punkt zlokalizowano w Górce prawie w geometrycznym środku posiadłości klasztornych na Ślęży i w jej okolicy. Materiał budowlany nieprzetworzony znajdował się w najbliższym sąsiedztwie budowy prepozytury i jej kościoła na terenach należących do klasztoru. Dlatego zrezygnowano z materiału zgromadzonego na stan. 25, jego transport na miejsce nowej budowy byłby bardzo trudny $\mathrm{i}$ całkowicie bezsensowny wobec istnienia tego surowca $\mathrm{w}$ promieniu kilkudziesięciu metrów.

W roku 2000 (Domański 2002, s. 106) przedstawiłem kilka domniemanych etapów budowy klasztoru (wtedy na szczycie). Przypuszczam, że przy zmianie lokalizacji i w świetle nowych odkryć w budowie klasztoru istniał okres wstępny, kiedy (może w porozumieniu z wysłannikami z klasztoru macierzystego) wykonano wstępne prace, jak gromadzenie materiałów, przygotowanie terenu. Kolejny etap to przybycie zakonników i prawie równoczesne rozpoczęcie prac budowlanych. Zakończenie (przerwanie) budowy mogło nastąpić wraz z ucieczką zakonników. Nieliczny materiał archeologiczny odkryty w miejscu budowy budynku klasztornego nie wskazuje na użytkowanie nawet jego części.

Proponowana lokalizacja klasztoru na krawędzi jego dóbr wskazuje, że administrowanie nimi nie było głównym celem budowy. Możliwość mieszkania w pierwszym okresie pobytu na Ślęży i perspektywicznie później ochrona fundatora była jednym $\mathrm{z}$ argumentów przy wyborze lokalizacji w pobliżu jego grodu w Będkowicach. Przy takim wariancie odpadała konieczność budowy prowizorycznych zabudowań drewnianych. Można było przystąpić do budowy kościoła i klasztoru w kształcie docelowym. Jednak w dalszym ciągu pozostaje zagadką etap, w jakim przerwano budowę. Zgromadzony materiał budowlany, ślady podwaliny jakiejś budowli, elementy kamieniarki i tablica ślężańska wskazują na przynajmniej rozpoczęcie budowy, jednak na jakim etapie ją zakończono, ciągle pozostaje zagadką.

Przypuszczalnie po decyzji o przerwaniu budowy jej teren stał się punktem, w którym zaopatrywały się budowy augustiańskie na Ślęży i w okolicy, także granitowe kościoły, klasztory i budowle świeckie fundowane przez Piotra Włosta i jego rodzinę (np. Wrocław-Piasek, Wrocław-Ołbin) (por. Lisowska 2013, s. $182-185,190)$.

Z budową klasztoru ślężańskiego wiąże się powszechnie „produkcję” granitowych posągów lwów, co istotne, odkrytych poza masywem jednak przez większość badaczy wiązanych z tym przedsięwzięciem (Hołubowicz, Hołubowicz 1952, s. 126-127, 135; Korta 1988, s. 188-192; Świechowski 1955, s. 60-66; 2011, s. 18-19). Wypada zgodzić się z większością historyków sztuki, że powstały one w XII wieku. Biorąc pod uwagę, że podobne posągi w architekturze zachodnioi południowoeuropejskiej były montowane parami w odrzwiach reprezentacyjnych budowli jako bazy kolumn, lwy ślężańskie (8) miały zdobić cztery reprezentacyjne wejścia, jeżeli jednak brać pod uwagę, że większości nie można pogrupować w pary (przeznaczone na dwie strony bram), można przypuszczać, że pierwotnie omawianych rzeźb było przynajmniej o kilka więcej. Jeżeli jednak dwa lwy sta- 
nowiły razem bazę kolumny (jak podobne lwy z Sankt Gallen znane fundatorowi), to liczba wejść zmniejszy się do dwóch lub trzech. Trzeba brać pod uwagę, że niektóre $\mathrm{z}$ nich od początku były uznane za nieudane. Według powszechnej opinii fachowców, większość $\mathrm{z}$ nich nie została użyta zgodnie z przeznaczeniem (por. uwagi Z. Świechowskiego 2011). Do dziś jeden z posągów wmurowany jest w kościół św. Jakuba w Sobótce, co można interpretować jako kontynuację tradycji zapoczątkowanej we wcześniejszym kościele romańskim posadowionym na tym samym miejscu, dwa w portal kościoła w Starym Zamku. Można przypuszczać, że dwa lwy odkryte w murach obiektów gospodarczych prepozytury w Sobótce-Górce mogły pierwotnie zdobić wejście do sąsiedniego kościoła lub być do tego przeznaczone. Co do lwa odkrytego w Garncarsku ze względu na miejsce znalezienia można przypuszczać, że mógł on być znakiem granicznym mimo braku oznaczenia znakiem X.

Same lwy już w momencie translokacji klasztoru do Wrocławia ze względu na swoją jakość nie nadawały się do użycia w stolicy księstwa (Korta 1988, s. 192). Przypuszczalnie także w okolicy Ślęży bardzo szybko stały się niemodne i były traktowane jako materiał budowlany. Nierozstrzygnięty jest problem braku lwów w miejscu budowy klasztoru. Lwy ślężańskie mają wiele cech wspólnych z podobnymi rzeźbami z klasztoru w Sankt Gallen, które, biorąc pod uwagę kontakty fundatora, mogły być pierwowzorami dla rzeźb ślężańskich.

\section{BIBLIOGRAFIA}

Bieniek S. 1965, Piotr Włostowic, postać z dziejów średniowiecznego Ślaska, Warszawa.

Błażejewski A. 1994, Archeologiczne badania terenowe przy źródle św. Jakuba na Ślęży, „Śląskie Sprawozdania Archeologiczne" 35, s. 349-354.

Braat W. 1937, Funde mittelalterlicher Keramik in Holland und ihre Datierung, „Bonner Jahrbücher” 142 , s. $157-176$.

Cehak-Hołubowiczowa H. (H. Hołubowiczowa), 1958, Ślęża i jej okolice w dziesięciolecie polskich badań archeologicznych, „Ślęża”, t. 1, s. 3-21.

Deptuła Cz. 1967, Przyczynek do dziejów Ślęży i jej opactwa, „Roczniki Humanistyczne Katolickiego Uniwersytetu Lubelskiego", t. 15, s. 17-35.

Derwich M. 1998, Monastycyzm benedyktyński w średniowiecznej Europie i Polsce, Wrocław.

Domański G. 1995, Nowo odkryte grodzisko na stokach góry Ślęży, „Śląskie Sprawozdania Archeologiczne" 36, 1995, s. 179-185.

- 1996, Badania wykopaliskowe grodziska na stokach Ślęży, „Śląskie Sprawozdania Archeologiczne” 38, s. 375-378.

- 1997, Wyniki badań grodziska wczesnośredniowiecznego na Ślęży, „Śląskie Sprawozdania Archeologiczne" 39, s. 461-463.

- 2000, Badania archeologiczne w masywie ślężańskim w latach 1998-1999, „Śląskie Sprawozdania Archeologiczne" 42, 199-206.

- 2002, Ślęża w pradziejach i średniowieczu, Wrocław 2002.

- 2005, Badania sondażowo-poszukiwawcze w masywie ślężańskim (Ślęża, Radunia) w 2000 roku, „Śląskie Sprawozdania Archeologiczne” 47, 55-66.

- 2006, Badania w masywie ślężańskim (Ślęża, Radunia) w latach 2003-2006, Wrocław 2006 (maszynopis w archiwum Oddziału Wrocławskiego IAE PAN). 
Dunin-Wąsowicz T. 1971, Saint-Gilles a Polska we wczesnym średniowieczu, „Archeologia Polski” 16, s. 651-665.

Van Es. 1969, Excavations at Dorestad; a Pre-preliminary Raport: 1967-1968, ROB 19, s. 183-212.

Geschwendt F. 1922, Vino bei Zobten, „Schlesische Geschichtsblätter” 2/3, s. 40-41

- 1926, Der Burgwall von Bankwitz Kreis Schweidnitz, Altschlesien, t. 1, s. 249-252.

- 1938, Der Siling, Land und Volk, Wrocław-Leśnica.

- 1942, Stand das Silingkloster auf dem Burggipfel oder in Gorkau, „Altschlesische Blätter” (Schlesische Blätter 1), s. 58-62

Hawrot J. 1949, Odkrycie budowli romańskiej w Sobótce, „Ochrona Zabytków” 2, s. 155-159

Hołubowicz H., Hołubowicz W. 1952, Z badań na Ślęży w1949 roku, „Studia Wczesnośredniowieczne” 1, s. $119-148$

Kastek T., Krzywka M., Limisiewicz A., Mruczek R. 2016, Ecclesia Sancte Marie de Monte Silencii albo o krótkiej karierze $i$ dtugich poszukiwaniach pewnego kościoła, w: Architektura sakralna w poczatkach państwa polskiego (X-XIII wiek), red. Tomasz Janiak, Dariusz Stryniak, Gniezno, s. 281-312.

Kastek T., Limisiewicz A., Mruczek R. 2013, Ecclesia sancte Marie de Monte Silencii? Nowo odkryte relikty budowli i rzeźb wczesnośredniowiecznych na szczycie Ślęży koło Sobótki, „Ślężańskie Światy", Wrocław, s. 302-320.

Kaźmierczyk J. 1994, Kamieniarze na Górze Ślęży w XII-XIII w. Wyniki badań uzyskane w latach 1991-1992, „Śląskie Sprawozdania Archeologiczne” 35, s. 355-360.

Kogut M. 2005, Ślężański klasztor, „Perspectiva, Legnickie Studia Teologiczno-Historyczne” 4/2, s. $85-101$

Korta W. 1964, Rozwój wielkiej własności feudalnej na Ślasku do połowy XIII wieku, Wrocław-Warszawa-Kraków.

- 1981, W sprawie lokalizacji klasztoru ślężańskiego, „Sobótka” 36, s. 27-33.

- 1988, Tajemnice góry Ślęży, Katowice.

Kozaczewski T. 1957, Jednonawowe kościoly romańskie na Dolnym Śląsku, „Zeszyty Naukowe Politechniki Wrocławskiej" 16, Architektura, Wrocław.

Lisowska E. 2013, Wydobycie i dystrybucja surowców kamiennych we wczesnym średniowieczu na Dolnym Ślasku, Wrocław.

Lustig G. 1925a, Der Peterstein am Zobtenberge, „Schlesische Monatshefte”, t. 2, s. 84-90.

- 1926, Vom Peterstein am Zobten, Altschlesien 1, 256-258.

- 1928, Die Anfänge des monumentalen Stiles in Schlesien, „Schlesiens Vorzeit, Neue Folge”, t. 9, s. $27-40$.

- 1928a, Schlesiens ältester Inschriftstein, „Altschlesien” 2, s. 126-128

- 1934, Die alte Wege am Siling, „Altschlesien”, t. 5, s. 344-350.

Maleczyński K. 1950, Zagadnienie góry Ślęży-Sobótki, „Materiały Wczesnośredniowieczne”, t. 2, s. 1-22,

- 1956, Kodeks dyplomatyczny Ślaska (CdS), t. 1, Wrocław

- 1960, Śląsk w epoce feudalnej, w: Historia Ślaska, Wrocław, s. 143-618.

Maleczyński K., Skowrońska A. 1959 Kodeks dyplomatyczny Śląska (CdS), t. 2, Wrocław.

Małachowicz E. 2000, Najnowszy zarys dziejów najstarszego Wrocławia, Wrocław.

Mandziuk J. 2007, Dzieje kanoników regularnych św. Augustyna na Ślasku, „Saeculum Christianum” $14 / 2$, s. $55-85$.

Matusik L. 1968, Kilka uwag w sprawie „Kroniki kanoników regularnych na Piasku we Wrocławiu”, w: Studia z dziejów kultury i ideologii, Wrocław 1968, s. 180-196

- 1974, Próba spojrzenie na postawe polityczna środowiska wrocławskich kanoników regularnych $w$ średniowieczu, s. 39-85.

Milis L. 1971, Les orgines des abbayes de Ślęża et du Piasek a Wrocław, „Roczniki Humanistyczne Katolickiego Uniwersytetu Lubelskiego" 19, z. 2, s. 5-27.

Pobóg-Lenartowicz A. 1992, Stan badań nad klasztorem kanoników regularnych NMP na Piasku we Wrocławiu, „Acta Universitatis Wratislaviensis. Historia”, s. 85-98.

- 1994, Uposażenie i działalność gospodarcza klasztoru kanoników regularnych we Wrocławiu, Opole. 
- 2007, A czyny ich byly liczne i godne pamięci. Konwent klasztoru kanoników regularnych NMP na Piasku we Wrocławiu do początku XVI wieku, Opole.

Semkowicz W. 1949, Góra Sobótka i jej zabytki polskie, Poznań-Wrocław.

Słupecki L.P. 1992, Ślęża, Radunia, Wieżyca. Miejsca kultu pogańskiego Słowian w średniowieczu, „Kwartalnik Historyczny”, t. 99, s. 3-15.

Stala K. 2010, Palatium możnowładcze Piotra Włostowica? Rekonstrukcja najstarszej fazy budowli romańskiej w Sobótce-Górce na podstawie najnowszych wyników badań archeologiczno-architektonicznych, „Wiadomości Konserwatorskie” 27, s. 67-78.

- 2010a, Ecclesia de novo constructa. Kościót kanoników regularnych w Górce koło Sobótki. Rekonstrukcja drugiej fazy przebudowy palatium możnowładczego Piotra Włostowica, ,Wiadomości Konserwatorskie" 28, s. 91-100

- 2011, Prezbiterium dawnego kościoła Kanoników Regularnych w Górce koło Sobótki. Uwagi w kontekście odkrytych pochówków, „Architektura, Czasopismo techniczne”, z. 23, rok 108, s. 471-486.

- 2013, Przemiany architektoniczne w zamku w Górce w okresie wczesnego średniowiecza, „Ślężańskie Światy", Wrocław, s. 289-302

Świechowski Z. 1955, Architektura na Śląsku do połowy XIII wieku, Warszawa.

- 2009, Katalog architektury romańskiej w Polsce, Warszawa.

- 2011, In monte silencii, „Architektura, Czasopismo techniczne” 7-A/2011, z. 23, s. 5-20 (Biblioteka Cyfrowa Politechniki Krakowskiej).

Uhtenwoldt H. 1936, Peter Wlast, der Siling und Breslau, Beiträge zur Geschichte des Stadt Breslau, t. 2, s. 32-102.

- 1937, Der Siling in der schlesischen Frühgeschichte, „Schlesische Heimat”.

- 1938, Der Peterstein am Siling und die schlesische Torkapelle, „Die Hohe Strasse”, t. 1, s. 72-85.

- 1940, Peter Wlast, Graf von Breslau, Wrocław.

Żerelik R. 1999, Dzieje Sobótki od średniowiecza do 1740 roku, w: W. Fabisiak, K. Popiński, J. Tyszkiewicz, R. Żerelik, Dzieje Sobótki, Sobótka, s. 24-58.

Zientara B. 2008, Bolesław Wysoki tułacz, repatriant, malkontent, Kraków. 